\title{
A Simplified Method for the Preparation of ${ }^{14} \mathrm{C}$-Labelled Branched-Chain $\alpha$-Oxo Acids
}

\author{
By H. W. Rüdiger, U. LANGENBeCK and H. W. Goedde \\ Institut für Humangenetik der Universität Hamburg, Martinistrasse 52, 2000 Hamburg 20, \\ German Federal Republic
}

(Received 10 November 1971)

The enzymic preparation of $\alpha$-oxo acids from their corresponding amino acids by using L-amino acid oxidase was introduced by Meister (1952). It is the aim of the present paper to describe a method adapted to the preparation of very small amounts of ${ }^{14} \mathrm{C}$-labelled branched-chain $\alpha$-oxo acids, 4-methyl-2oxopentanoic acid ( $\alpha$-oxoisocaproic acid), 3-methyl2 -oxopentanoic acid ( $\beta$-methyl- $\alpha$-oxovaleric acid) and 3-methyl-2-oxobutyric acid ( $\alpha$-oxoisovaleric acid), which are volatile in the free state and undergo rapid base-catalysed decomposition. These $\alpha$-oxo acids arise physiologically from leucine, isoleucine and valine, and accumulate in an inherited metabolic disorder, maple-syrup urine disease (Menkes et al., 1954).

\section{Materials and methods}

$\mathrm{L}-\left[\mathrm{U}-{ }^{14} \mathrm{C}\right]$ Leucine, $\mathrm{L}-\left[\mathrm{U}-{ }^{14} \mathrm{C}\right]$ isoleucine, $\mathrm{L}-\left[\mathrm{U}-{ }^{14} \mathrm{C}\right]-$ valine, $\mathrm{L}-\left[1-{ }^{14} \mathrm{C}\right]$ leucine and $\mathrm{DL}-\left[1-{ }^{14} \mathrm{C}\right]$ valine were obtained from The Radiochemical Centre (Amersham, Bucks., U.K.), and L-[1-14C]isoleucine was from Calbiochem (Los Angeles, Calif., U.S.A.). L-Amino acid oxidase (EC 1.4.3.2) and catalase (EC 1.11.1.6) were purchased from Boehringer (Mannheim, German Federal Republic). Dowex 50W (X8; 200-400 mesh) was purchased from Serva (Heidelberg, German Federal Republic). All other substances, including the silica-gel t.l.c. plates, were from Merck (Darmstadt, German Federal Republic).

A $50 \mu \mathrm{Ci}$ portion of freeze-dried amino acid (specific radioactivity usually $10-20 \mathrm{mCi} / \mathrm{mmol}$ ) was dissolved in two $500 \mu \mathrm{l}$ portions of distilled water and pipetted into a $14 \mathrm{ml}$ Warburg vessel. Then $500 \mu 1$ of $1 \mathrm{M}$-tris- $\mathrm{HCl}$ buffer, $\mathrm{pH} 7.7,50 \mu \mathrm{l}$ of catalase solution and $200 \mu 1$ of L-amino acid oxidase solution were added in that sequence, yielding a total volume of $1750 \mu 1$. The vessel was gassed for $1 \mathrm{~min}$ with $\mathrm{O}_{2}$, closed tightly and incubated with continuous shaking for $3 \mathrm{~h}$ at $37^{\circ} \mathrm{C}$. After $1 \mathrm{~h}$ the gassing with $\mathrm{O}_{2}$ was repeated.

To separate the $\alpha$-oxo acid from the remaining amino acid, Dowex 50W (X8) was washed successively with $1 \mathrm{M}-\mathrm{NaOH}$, water, $1 \mathrm{M}-\mathrm{HCl}$ and water, and was packed in a $10 \mathrm{~mm} \times 70 \mathrm{~mm}$ column. The whole reaction mixture was gently applied to the column, and elution was carried out with distilled water, the flow rate being adjusted to about 1 drop/8-10s. A $5 \mu 1$ sample of each $1 \mathrm{ml}$ fraction was taken for determination of radioactivity in a Packard liquidscintillation spectrometer. The purity of the eluted $\alpha$-oxo acid was checked by t.l.c. on silica gel with water-saturated butan-1-ol containing formic acid $(5 \%, w / v)$ as solvent. Distribution of radioactivity on the chromatogram was detected with a model II thinlayer-chromatographic scanner (Berthold, Wildbad, German Federal Republic).

\section{Results and discussion}

The yield of $\alpha$-oxo acid by using our method is about $80 \%$ with L-amino acid and about $40 \%$ with DL-amino acid. Prolonged incubation of the enzyme reaction mixture for more than $3 \mathrm{~h}$ did not result in any further increase in the yield. Removal of enzyme protein before Dowex chromatography could be omitted, because the protein remained on top of the column without seriously affecting the flow rate. Under these conditions the amino acid is retained in the column and discarded together with the small amount of resin needed in this procedure. The $\alpha$-oxo acid usually appeared in the fifth and sixth $1 \mathrm{ml}$ fractions. The $\mathrm{pH}$ of these fractions was about 1.5. As most $\alpha$-oxo acids undergo base-catalysed decomposition even in neutral solution and are fairly stable in an acidified solution (von Korf, 1964), we kept the whole batch deep-frozen and neutralized the amount required just before use. No decomposition was observed after storage at $-20^{\circ} \mathrm{C}$ for at least 1 month. On the other hand, 3 days after neutralization radioactive impurities could be detected by t.l.c., and these resulted in high background values in our enzymic test when these $\alpha$-oxo acids were used as substrates (Goedde et al., 1964; Rüdiger et al., 1971). Because 3-methyl-2-oxopentanoic acid undergoes spontaneous racemization at alkaline $\mathrm{pH}$, it must be neutralized carefully; this we did by raising the $\mathrm{pH}$ to 6.8 with $0.3 \mathrm{M}$-phosphate buffer, $\mathrm{pH}$ 7.0.

This work was supported by grants from the Deutsche Forschungsgemeinschaft.

Goedde, H. W., Richter, W., Hüfner, E. \& Sixel, B. (1964) Klin. Wochenschr. 42, 818 
Meister, A. (1952) J. Biol. Chem. 197, 309

Menkes, J. H., Hurst, P. L. \& Craig, J. M. (1954) Pediatrics 14,462
Rüdiger, H. W., Nikisch, M. \& Goedde, H. W. (1971) J. Chromatogr. 61, 373

von Korf, R. W. (1964) Anal. Biochem. 8, 171 